\title{
Lysine genetically enriched cereals for improving nutrition in children under 5years in low- and middle- income countries
}

\begin{abstract}
Nutrition is not evenly adequate in the world because malnutrition is increasing at the expense of overweight and obesity and although its other component under nutrition is receding it is a quantity and qualitatively reality still too important in Low- and MiddleIncome Countries. The absolute figures and trends are a matter of concern at individual, national and international level. Essential amino acids (not synthesized by humans) are not completely present in plants or crops that are an important, if not the only food available for people living in certain wide areas such as Sub-Saharan Africa. Basic genetic and genetic engineering technologies initiated in mid of the past century have evolved at a fast rate allowing improving this lacking problem. Therefore great advantages have been achieved in transforming maize but also rice, wheat and other cereals but not sorghum. This long procedure of transformation for cereals nowadays mostly by private companies is heavily affected by economical costs and fund recovery and in addition on the irrational opposition of certain administrations and some social sectors rejection of these safe procedures. The humanitarian aspect of transformation should prompt governs and high health organization to assess and solve the problem. The safety of the products is widely admitted.
\end{abstract}

Keywords: essential amino acids, lysine, genetic engineering, transformed cereals, under nutrition, micronutrients, under-five children
Volume 5 Issue 2 - 2016

\section{Manuel Moya}

Professor of Pediatrics, University Miguel Hernandez, Spain

Correspondence: Manuel Moya, Professor of Pediatrics, University Miguel Hernandez, Campus de S. Juan. Alicante, Spain, Email Manuel.moya@umh.es

Received: October 19, 2016 | Published: November 21, 2016
Abbreviations: HIC, high income countries; WHO, world health organization; LPI, lysinuric protein intolerance; QPM, quality protein maize; DHDPS, di hydro di picolinate synthase; LMIC, low and middle-income countries

\section{Introduction}

It is important to determine first the context of Under nutrition and make clear that Malnutrition (bad nutrition) includes both Under nutrition and Obesity. ${ }^{1}$ Under nutrition can be defined as inadequate nutrition resulting from lack of food (plus other factors) or failure of the body to absorb or assimilate nutrients properly. At present it is evaluated through the widely recognized Z-score system ${ }^{2}$ being under nutrition and underweight respectively $\mathrm{Zs}<-2 \mathrm{SD}$ and $<-1 \mathrm{SD}$ to $<-2$ SD. These limits are important due to the vast majority of under weights frequently are overlooked. Other terms such as stunting $(<-$ 2SD from median height) are less informative if the target height is not known. Classical terms are less used probably because they are largely arbitrary. Due to the advances in the biochemical measurements, the under nutrition concept includes the micronutrient deficiencies also known as Hidden hunger and it is pertinent to say that the classical 'big four' (vitamin A, zinc, iodine and iron) have been expanded although not evenly. Also the concept of Food security (access to food for all) although with a more epidemiological background has proved quite useful because its application has allowed discovering populations with moderate under nutrition even in high income countries (HIC).

The other relevant aspect is the prevalence of under nutrition in children under 5 , a period of special health relevance according to the WHO Global Health Observatory in which infections are a real threat with a higher mortality rate especially in LMIC. The good news is that this health problem is receding all over the world: In 1960 there were 300million that in 2015 went down to 113 million (-33\%), but the problem is still important especially in South Asia with 28.7million and Sub-Saharan Africa ( $>50$ countries) with 51.3million of under-five ${ }^{3}$ These worrying figures will continue because the world population by 2050 will be of 9.1 billion, whereas the developed countries will increase by $6 \%$, South Asia will do by $48 \%$ and SubSaharan Africa by $130 \%$. Consequently malnutrition as the present double burden that is the coexistence of underweight and overweight will go on according to the United Nations Population Division. ${ }^{4}$

Beyond the present scope are the epigenetic modifications, whether reversible or not.

\section{Essential amino acids}

Lysine is an essential amino acid (humans don't synthesize it) with important biological roles many of them related to the $\varepsilon$ amino group. Classically these roles have been carried out through protein synthesis therefore with a wide scope of actions on the brain, muscle protein synthesis, synthesis of enzymes, hormones, antibodies, opsins, calcium absorption. As result lysine deficiency will affect growth and development in children. At this point it should be remembered that lysine is likely the limiting amino acid in cereals even in wheat. The animal experiences were the earliest and best known: Pigs fed with genetically Lys-enriched maize (opaque o2 food) weighed $30 \mathrm{~kg}$ more than the control fed unmodified maize. ${ }^{5}$ In fact lysine is industrially 
obtained at present in large amounts after microbial fermentation of sugars (or methanol) becoming an important additive for pigs and chicken food ${ }^{6}$ due to the improvement in weight and size. Carnivore and herbivore animals are less important models conversely omnivore animals (pigs) are of greater significance because lysine is most often the limiting amino acid in their diets. ${ }^{7}$

In humans the specificity of lysine deficiency is scanty because of the habitual coincidence with other lacking nutrients and the ethically impossible randomized controlled trials. Furthermore foods from locally available products (incomplete protein cereals) are deeply rooted in the population of LMIC and the possibility of blending or adding animal protein are limited as it has been demonstrated in the crucial period when complementary feeding must be established. ${ }^{8}$

The requirements of lysine for the moment follow the directions of the $\mathrm{WHO} / \mathrm{FAO} / \mathrm{UNU}$ report. ${ }^{9}$ that simplifying go from $60 \mathrm{mg} / \mathrm{kg} / \mathrm{day}$ in the first year to $45 \mathrm{mg} / \mathrm{kg} /$ day in the second year, down to $30 \mathrm{mg} /$ $\mathrm{kg}$ /day at 18 years which is the recommended amounts for adults. These figures probably need to be reconsidered in the lights of some evidence based studies. ${ }^{10}$ These requirements mean that a child of one year and $9 \mathrm{~kg}$ will require $\sim 500 \mathrm{mg}$ of lysine per day. To get this amount from maize $(27 \mathrm{mg} / \mathrm{g}$ of protein) or sorghum $(20 \mathrm{mg} / \mathrm{g}$ of protein), this would imply to eat $250 \mathrm{~g}$ per day of sorghum flour which is unrealistic besides being a monotonous and hypoproteic diet.

A more accurate evaluation of lysine deficiency in humans has been offered by some inherited diseases of metabolism. The first condition is Glutaric aciduria type I in which a free lysine diet is an important part among other measures beyond this approach. Thirty three patients were accurately followed during the first six years of life. ${ }^{11}$ And depending on the degree of affectation of the children; low lysine diet resulted in reduced weigh gain or linear growth retardation. The other entity is Lysinuric protein intolerance (LPI) in which the impaired transport of dibasic amino acids leads to low levels of lysine but also of arginine and ornithine although the last two are corrected by the daily administration of citrulline. The Finn series ${ }^{12}$ particularly in undiagnosed children and adults also avoiding protein-rich food as a protective mechanism, they showed mental retardation and hypotonic in different degrees. The neurological manifestations can be related to lysine deficiency and many of the clinical features of LPI (osteoporosis, growth retardation, liver and spleen enlargement, interstitial pneumonitis) have been previously related to lysine deficiency. ${ }^{13}$ More recently and coming back to human Under nutrition a study supported by the Washington University of St. Louis showed specifically that chronic inadequate intake of essential amino acids is linked to stunting in Malawi. ${ }^{14}$

\section{Transformation technologies for cereal derived foods}

The basis for transforming (improving genetically their quality) cereals is that they provide more food energy in the whole world that any other crop covering human and livestock consumption. The most important for human use are rice, wheat, maize and sorghum, although consumption is far from even because of climate conditions, soil quality and water requirements for cultivation. The good adaptation of sorghum to arid climates justifies its high production in some countries of the Sub-Saharan Africa and South-Central Asia. This important nutritional source for so many people is far from perfect and in addition has an Achilles heel which is the low content of the essential amino acid lysine (Table 1). This precariousness in comparison to soybean flour and the reference standard of complete protein is evident for all cereals including sorghum. Then techniques of basic genetics and genetic engineering have successfully been used to enrich the content in the grain of some essential amino acids particularly lysine in the mentioned crop plants as well as other achieved improvements (vitamin A). The genetic attempts were restricted to 'quality protein maize' (QPM) plant variety which were enriched in lysine in the seed but not in other gramineae perhaps for poor plant breeding and difficulties for inserting the high lysine trait into the seeds. Conversely genetic engineering techniques were able to achieve the seed expression of specific traits through specific promoters. The paradigmatic high-lysine opaque 2 mutant ${ }^{15}$ is probably the first successful genetic approach because of the diminished lysine-poor seed storage proteins (zein) together with an increase in high-rich non-zein proteins as well as free lysine and other amino acids. This proved not only to increase growth in animals but also the benefit on under 5 as the classical studies carried out nearly fifty years ago on Guatemalan young children suffering from Kwashiorkor. This was the first step over which the Maize and Wheat Improvement Center generated the opaque2-derived QPM lines with normal agronomic traits absent in previous cultivars. One of the most relevant achievements was the reduction of $\alpha$ - and $\beta$-zein storage proteins. The use of the new techniques gathered under the concept of genetic engineering have opened a vast field of possibilities and new ones are coming almost every day, but time will elucidate their survival. At the present moment the first approach based on the alterations of the biosynthetic and catabolic of lysine pathways is still in use. The first biosynthetic step of lysine is regulated by dihydrodipicolinate synthase (DHDPS) which is retro inhibited by lysine. ${ }^{16}$ The catabolic path is regulated by the LKR/ SDH enzyme. A combination of the traits of DHDPS expression and LKR/SDH suppression and expression of genetically engineered high-lys proteins all in the endosperm show their greatest potential for producing maize (and also in other cereals) with an acceptable lysine content together with minimal penalties on crop growth and yield. In general to develop complete protein containing the essential and limiting amino acids at appropriate level, the genetic engineering technique uses four approaches ${ }^{17} 1$ modifying seed protein bodies, 2 modulating certain biosynthetic/catabolic pathways, 3 increasing nitrogen relocation in the grain using transgenes and 4 incorporating new genetic variances, these approaches can be used in combination. Furthermore advances in nutrigenomics and nutrigenetics can improve food quality at a rapid pace and consequently in the human sector the health level. These techniques can be transversally used as happened in rice ${ }^{18,19}$ or wheat, ${ }^{20}$ although the greater experience with newer applications and results come from maize..$^{21,22}$ The progress in this important field that improves food quality can be appreciated by the various database ${ }^{23}$ that are similar to those of human data on genome, exome, gene alterations, SNIPS and epigenetic changes. For more detailed information on these aspects see the specific publications elsewhere. ${ }^{24-27}$

Sorghum, All the progress shown has not been possible to apply to sorghum transformation despite the relation to maize as both are members of the same pamicoideae subfamily. The first attempts to transform it are from 1973 after the introduction of a mutant gene that increased lysine content in sorghum bicolor grain. ${ }^{27}$ Afterwards there were a couple of clinical studies on protein absorption in children of less than two years using the untransformed sorghum plant but externally added lysine. ${ }^{28}$ In this descriptive time it is worth to mention the studies on the amino acid composition of the whole sorghum grain ${ }^{29,30}$ and its relationship to the nitrogen and protein content. ${ }^{31}$ Not surprisingly lysine was the limiting amino acid and 
total protein content in the lower limit in order to supply the required amount of $\sim 1 \mathrm{~g} / \mathrm{kg} /$ day, these would be a disadvantage at the crucial period for neurodevelopment going from birth to the 2nd birthday, or better in the first 1000days of life. More recently transformed sorghum cultivars have been proposed as a means for decreasing cadmium in contaminated soils. ${ }^{32}$

At present neither basic genetic nor genetic engineering have successfully been used for improving lysine content in sorghum transformed plants and it is well known that the enrichment of essential amino acids in crop plants is prompted by both economical and humanitarian reasons. In HIC this interest is basically for animal foods due to the fact that animal derived foods for humans normally supply enough essential amino acids. In LMIC where plant derived food cover the regular feeding for people, the humanitarian aspects should be preeminent and requiring economical support by national or international bodies. At least three private companies, one in lights of CRISP technology approached sorghum transformation but finally desisted to my knowledge. This is a pity because untransformed sorghum bicolor (cultivars theoretically too) have proved to be resilient to low water supply, soil conditions or to infections by pathogens and even have the advantage that its gluten-like protein is different from that of wheat and devoid of toxicity. ${ }^{33}$

Table I Essential amino acids and protein content in different cereal products in comparison to the complete protein pattern and soybean flour

\begin{tabular}{|c|c|c|c|c|c|c|}
\hline & Complete & Soybean & Rice & Wheat & Maize & Sorghum \\
\hline & $\begin{array}{l}\text { Protein } \mathrm{mg} / \mathrm{g} \\
\text { prot }\end{array}$ & Flour mg/g prot & White $\mathrm{mg} / \mathrm{g}$ prot & t Flour mg/g prot & Whole $\mathrm{mg} / \mathrm{g}$ prot & Grain $\mathrm{mg} / \mathrm{g}$ prot \\
\hline Trp & 7 & 14 & 13 & 12 & 9 & 10,2 \\
\hline Thr & 27 & 42 & 36 & 29 & 37 & 31,2 \\
\hline Ile & 25 & 50 & 46 & 46 & 38 & 42,1 \\
\hline Leu & 55 & 85 & 89 & 77 & 133 & 140,8 \\
\hline Lys & 51 & 70 & 39 & 22 & 27 & 20,2 \\
\hline Met+Cys & 25 & 28 & 40 & 33 & 41 & 16,6 \\
\hline Phe+Tyr & 47 & 88 & 87 & 89 & 92 & 53,3 \\
\hline Val & 32 & 53 & 63 & 43 & 46 & 52,2 \\
\hline His & 18 & 28 & 25 & 20 & 27 & 20,6 \\
\hline Prot g/l00g & & 36 & 8 & 12 & 8 & 10,4 \\
\hline
\end{tabular}

\section{Safety}

In the last decade of last century the irrational and fostered attitude of certain society sectors against the risks of incorporating the genes of 'transgenic food' into the human genome were quite spread in some European countries. We decided at that moment to publish an article ${ }^{34}$ analyzing the fate of ingested DNA and the already proven benefits of genetic modified food. It is still surprising how this idea of danger or dismissal is still alive in some social sectors and the existence of legal shackles from EU (GMO Authorization 2015 protocol) and national governments for transformed foods. Coming back to lysine- enriched foods the content of this amino acid in transformed maize goes from $70 \%$ to $54 \% .^{35,36}$ The content in the unmodified plants are of $27 \mathrm{mg} / \mathrm{g}$ of protein, these gains are not exaggerated and no adverse issues were published in livestock (mainly pig and chicken). In this way are the data from rats fed for 3months with Y642 transgenic maize with no adverse results in clinical, chemical and on pathological grounds when the toxicological protocol was applied also to the control group. In humans we could take advantage again from the Familial hyperlysinemia an autosomal recessive and benign disease. In a follow up study from birth up to 24years of these patients ${ }^{37}$ with lysine plasma levels of $20 \mathrm{mg} / \mathrm{dl}$ (normal range $1.2-3.5 \mathrm{mg} / \mathrm{dl}$ ) mental development was normal and no adverse effects were detected, even a normal child was born to a mother with hyperlysinemia, this is in agreement with the classical knowledge of no evidence that amino acids derived from usual or even high protein food present any risk, another thing is the case of dietary supplements. ${ }^{38}$

To end these considerations on lysine enriched cereals for human foods it is pertinent to consider the advantages of an adequate nutrition. This implies better health and socioeconomic status for any population or group, especially under 5 , after moving from the under nutrition status in the three aspects of energy, protein and micronutrients to normal nutritional status, which normally requires a certain period of time. Also the evolution of population should be considered in some parts of the world, it was mentioned how the SubSaharan Africa will grow by $130 \%$ by 2050 and this probably with the same food resources. Nutrition is relevant among the different factors acting on the 'intergenerational cycle' concept. ${ }^{39}$ In this case an appropriate nutrition in infancy, then in childhood and adolescence, and in adult or adolescent pregnant women (first 1000days of life) will lead to a full term newborn. Present transforming capacities could contribute to this positive cycle.

\section{Acknowledgements}

None.

\section{Conflict of interest}

Author declares that there is no conflict of interest. 


\section{References}

1. UNICEF/WHO/WORLD. BANK GROUP: Joint Child Malnutrition Estimates. 2016

2. World health organization (WHO) Global database on child growth and malnutrition. World Bank, Africa.

3. Dewey KG, Borghi E, Onyango AW, et al. The World Health Organization's global target for reducing childhood stunting by 2025 : rationale and proposed actions. Matern Child Nutr. 2013;9(Suppl 2):6-26.

4. UN Department of Economics and Social Affairs. World Population Prospect 2016

5. Corn AH. Rockefeller Foundation the Concise Encyclopedia of Food \& Nutrition. In: Ensminger ME, editor. 1995. 235p.

6. Proagrica Media. Norwegian granted for improving Lysine production process. 2010.

7. Ball RO, Urschel KL, Pencharz PB. Nutritional consequences of interspecies differences in arginine and lysine metabolism. J Nutr: 2007;137(Suppl 2):1626s-1641s

8. Suri DJ, Tano Debrah K, Ghosh SA. Optimization of the nutrient content and protein quality of cereal-legume blends for use as complementary foods in Ghana. Food Nutr Bull. 2014;35(2):372-381.

9. WHO/FAO/UNU. Protein and amino acid requirements in human nutrition. WHO Technical Report Series. Geneva; 2009. 136p.

10. Millward DJ. Identifying recommended dietary allowances for protein and amino acids: a critique of the $2007 \mathrm{WHO} / \mathrm{FAO} / \mathrm{UNU}$ report. $\mathrm{BrJ}$ Nutr. 2012;108 (Suppl 2):s3-s21.

11. Boy N, Haege G, Heringer J, et al. Low lysine diet in glutaric aciduria type I- effect on anthropometric and biochemical follow-up parameters. J Inherit Metab Dis. 2013;36(3):525-533.

12. Tanner LM, Näntö-Salonen K, Venetoklis J, et al. Nutrient intake in lysinuric protein intolerance. J Inherit Metab Dis. 2007;30(5):716-721.

13. Simell O Lysinuric Protein Intolerance and other Cationic Amino Acidurias. In: Scriver, editor. The Metabolic Basis of Inherited Diseases. New York: McGraw-Hill; 1989. p. 2496.

14. Manary MJ. Dietary link to stunted growth identified. 2016

15. Mertz ET, Bates LS, Nelson OE. Mutant Gene that Changes Protein Composition and Increases Lysine Content of Maize Endosperm. Science. 1964;145(3629):279-282.

16. Karchi H, Shaul O, Galili G. Lysine synthesis and catabolism are coordinately regulated during tobacco seed development. Proc Nat Acad Sci USA. 1994;91(7):2577-2581.

17. Wenefrida I, Utomo HS, Linscombe SD. Mutational breeding and genetic engineering in the development of high grain protein content. $J$ Agric Food Chem. 2013;61(48):1702-1710.

18. Kawakatsu T, Takaiwa F. Differences in transcriptional regulatory mechanisms functioning for free lysine content and seed storage protein accumulation in rice grain. Plant cell Physiol. 2010;51(12):1964-1974.

19. Liu X, Zhang C, Wang X, et al. Development of high-lysine rice via endosperm-specific expression of a foreign lysine rich protein gene. BMC Plant Biol. 2016;16(1):147.

20. Hoisington D. Opportunities for nutritionally enhanced maize and wheat varieties to combat protein and micronutrients malnutrition. Food Nutr Bull. 2003;23(4):376-377.
21. Chang Y, Shen E, Wen L, et al. Seed-specific expression of the Arabidopsis AtMAP18 gene increases both lysine and total protein content in maize. Plos One. 2015;10(11):e0142952.

22. Almeraya EV, Sanchez-de-Jimenez E. Intragenic modification of maize. J Biotechnol. 2016;238:35-41.

23. Liu H, Wang F, Xiao Y, et al. MODEM: multi-omics data envelopment and mining in maize. Database (Oxford). 2016.

24. Thao NP, Tran LS. Enhancement of plant productivity in the postgenomics era. Curr Genomics. 2016;17(4):295-296.

25. Kamthan A, Chaudhuri A, Kamthan M, et al. Genetically modified (GM) crops: milestones and new advances in crop improvement. Theor Appl Genet. 2016;129(9):1639-1655.

26. Altpeter F, Springer NM, Bartley LE, et al. Advancing crop transformation in the era of genome editing. Plant Cell. 2016;28(7):1510-1520

27. Signh R, Axtell JD. High lysine mutant gene (hl) that improves protein quality and biological value of grain sorghum. Crop Sci. 1973;13:535-539.

28. Nuclean WC, Lopez de Romaña G, Gastanaduy A, et al. The effects of decortication and extrusion on the digestibility of sorghum by preschool children. J Nutr. 1983;113(10):2071-2017.

29. MacLean WC, Lopez de Romaña G, Placko RP, et al. Protein quality and digestibility of sorghum in preschool children; balance studies and plasma free amino acids. J Nutr. 1981;111(11):1928-1936.

30. Mossé J, Huet JC, Baudet J. the amino acid composition of whole sorghum grain in relation to its nitrogen content. Cereal Chemistry. 1988;65(4):271-280

31. Hikerwal M. Mathieson AR The protein content and amino acid composition of sorghum grain. Cereal Chemistry. 1971;48:690-697.

32. Jia W, Lv S, Feng J, et al. Morphophysiological characteristic analysis demonstrated the potential of sweet sorghum (sorghum bicolor(L.) Moench) in the phytoremediation of cadmium-contaminated soils. Environ Sci Pollut Res Int. 2016;23(18):18823-18831.

33. Konig F. Adverse effects of wheat gluten. Ann Nutr Metab. 2015;67(suppl 2):218-214.

34. Ballabriga A, Moya M. Alimentos transgénicos. An Pediatr (Barcelona). 1990;50:1-9.

35. Yu J, Peng P, Zhang X, et al. Seed-specific expression of the lysine-rich protein gene sb401 significantly increases both lysine and total protein content in maize seeds. Food Nutr Bull. 2005;26(4):427-431.

36. He XY, Tang MZ, Luo YB, et al. A 90day toxicology study of transgenic lysine-rich maize grain (Y642) in Sprague-Dawley rats. Food Chem Toxicol. 2009;47(2):425-432.

37. Dancis J, Hutzler J, Ampola MG, et al. The prognosis of hyperlysinemia: an interim report. Am J Hu Genet. 1983;35(3):438-442.

38. JJ Otten JP Hellwig LD. Meyers DRI Dietary Reference Intakes. Protein and Amino Acids. Washington: The National Academies Press; 2001. $144 \mathrm{p}$.

39. United Nations System. Standing Committee on Nutrition. Maternal nutrition and intergenerational cycle of growth failure. 1998. 